Свтушенко О. В., аспірант

Артюх Т. М., Д.т.н., професор

Київський національний університет

імені Тараса Шевченка

м. Київ, Украӥна

DOI: https://doi.org/10.30525/978-9934-26-107-7-9

\title{
ЕКОЛОГІЧНІ АСПЕКТИ ФОРМУВАННЯ РИНКУ ТОВАРІВ ПОБУТОВОЇ ХІМІЇ В УКРАЇНI
}

Розвиток ринкової економіки та вимоги міжнародних екологічних та органічних стандартів спрямовують на теоретичне переосмислення і практичну реалізацію завдань, які пов'язані 3 оптимізацією товарного асортименту виробничого, торгівельного підприємства, зокрема i в електронній комерції, що забезпечує конкурентну перевагу товару на ринку, безпечність, екологічну чистоту, соціальну відповідальність та прибутковість підприємства.

Обсяг ринку екологічної продукції по групі товарів побутової хімії, зокрема засобів для миття та чищення, прання, миття посуду і засобів особистої гігієни у 2019 році оцінюється в 0,5 млрд. грн. і щорічно зростає разом із загальним рівнем виробництва, платоспроможного попиту, а також внаслідок залучення додаткових сегментів споживачів. Відмічається постійне збільшення споживання екотоварів в Україні. За даними моніторингу ринку (2018-2020рр.), обсяги роздрібної торгівлі екотоварів у 2019 році зросли на 4,3\% в порівнянні з поточним роком i ця тенденція продовжує зростати [1]. Товарообіг продукції в екосегменті залежить від глобальних економічних тенденцій, зокрема пов'язаних і 3 пандемією Covid 19, що зумовило збільшення продажів товарів побутової хімії та особистої гігієни. У структурі виробництва мийних та чистячих засобів в Україні, частка екопродукції займає лише 3-4\%.

Крім проблеми попиту, ринок екотоварів зустрічається 3 проблемою грінвошингу - спекуляції на темі екології, «зеленого» 
продукту. Це явище обумовлене бажанням виробників отримати додатковий прибуток, збільшити лояльність споживачів шляхом введення їх в оману, застосовуючи елементи яскравого та тематичного маркування. Сьогодні, наявність екологічного маркування за відсутності екологічного сертифікату, який видається за умов відповідності світовим або вітчизняним екологічним критеріям, карається Законом.

До критеріїв оцінки екопродукції відносять такі показники: більше $40 \%$ вмісту інгредієнтів природного походження; відсутність речовин: I, II і III класу небезпеки, озоноруйнуючих і фосфоровмісних; більше 80\% ступінь біорозкладання ПАР; регламентований рівень токсичності; обмежений перелік вмісту ароматизаторів; придатна до переробки упаковка тощо.

Крім цього, екологічна безпечність продукції контролюється i органічними стандартами. До базових вимог органічних стандартів щодо продуктів переробки належать такі: 95\% вміст сировини органічного походження, решта 5\% - 3 дозволеного списку; заборона на застосування синтетичних добавок; заборона на вміст хлору, фосфатів і аніонних ПАР (максимум 5\%) у складі продукції побутової хімії.

Отже, питання споживання екопродукції та формування товарного асортименту залежать від пропозиції підприємства, платоспроможного попиту споживачів. На збільшення виробництва та споживання екотоварів впливає рівень нормативноправового забезпечення країни та свідомий вибір споживачів. Дослідження цих чинників, дозволить правильно побудувати асортименту політику екологічно-орієнтованого виробничого підприємства та зайняти вигідну позицію на ринку. Зважаючи на ці аспекти тема $є$ актуальною та своєчасною.

Загальні тенденції споживання товарів побутової хімії та засобів гігієни в Україні характеризуються динамікою основних економічних показників. Зокрема, зниження реальних доходів населення у зв'язку з пандемією 2020 р. спричинило зменшення споживання товарів, що не входять до списку предметів першої необхідності. У групі товарів побутової хімії - це кондиціонери 
для білизни, засоби, що освіжають повітря, поліролі, спеціалізовані засоби для чищення (наприклад, для кахлю). У групі товарів косметика - зниження частоти покупок відбулося для засобів по догляду за обличчям (спеціалізовані засоби для очищення, лосьйони, маски, сироватки).

Порушення правил маркування, законодавчо закріплених в Директивах, Технічних регламентах та Законах, відбувається шляхом нанесення на первинне упакування продукції фраз або малюнків, щодо дотичності до екотовару без наявності екосертифікату. Це забезпечує звичайному товару більш якісне позиціювання в цьому сегменті, що не відповідає дійсності.

Засобами грінвошингу досягається асоціювання товару 3 більш якісним та екологічно чистим шляхом:

- застосування назви товару зі словами екологічної тематики на кшталт «Natural, Bio, Green» тощо;

- використання зображень, що асоціюються 3 чистотою та живою природою - листя, вода, планета; зображення дітей; свіжих фруктів;

- запозичення виразів, що не підтверджені документально «безпечний», «екологічний», «натуральний»;

- акцентування на споживчої переваги, яка не має підтвердження в маркування, до прикладу «з натуральних інгредієнтів» (при низькому вмісту таких інгредієнтів або при високій частці натуральних речовин, шкідливих для людини або навколишнього середовища);

- запозичення екологічної характеристики упаковки для рекламування неекологічної продукції на етикетці, основній упаковці (тарі) - продаж товару в екоупаковці (паперових пакетах, упаковці з вторсировини тощо);

- рекламування та оцінка некомпетентних організацій, що вводять в оману щодо наукового обгрунтування даної рекомендації;

- неправомірне використання «екологічного маркування» тощо. 
Отже, грінвошинг вводить в оману споживачів та знижує споживну цінність екопродукції, а при отриманні негативної реакції, може викликати й негативну реакцію на інші екотовари.

Стратегія розвитку екоринку в Україні закладена в державному акті «Основні принципи державної екологічної політики України на період до 2020 року». Декларування необхідності посилення екологічної безпеки шляхом розробки підсистеми стандартизації і сертифікації, затвердження екологічних вимог до продукції, а також гармонізації національних стандартів до стандартів і норм СС і міжнародних стандартів серій ISO 14000 , ISO 19000 є сьогодні тим мінімальним переліком заходів, що дозволить країні побудувати світле та чисте майбутнє, зростити здорове покоління. В Стратегії зроблено акцент на посилення контролю 3 боку держави за використанням екологічних маркувань, позначень щодо вмісту генетично модифікованих організмів.

До обов'язкових вимог, що встановлюються сьогодні до мийних засобів і поверхнево-активних речовин, що входять до їх складу, є обмеження по вмісту фосфатів та інших сполук фосфору [«Технічний регламент мийних засобів», затверджений постановою Кабінету Міністрів України від 20 серпня 2008 № 717]. Технічний регламент чітко регламентує вміст фосфору у пральному порошку, який має бути менше 0,5 грам в рекомендованій кількості для основного циклу прання в жорсткій воді (для стандартного завантаження пральної машини). Ця вимога набула чинності з 2015 року [Постанова Кабінету Міністрів України від 12 червня 2013 № 408].

Ці нормативно-правові документи передбачають поступовий перехід до повної заборони фосфатної побутової хімії в країні. Законопроектом передбачається заборона виробництва, імпорту й реалізації на території України синтетичних мийних засобів та товарів побутової хімії, у складі яких масова частка фосфатів у перерахунку на $\mathrm{P}_{2} \mathrm{O}_{5}$ (загальний фосфор) становить понад 0,7-0,5\%, а також особлива увага буде надана продукції з вмістом 
хлору та його з'єднань. На даний момент розглядається ще кілька проектів законів, пов'язаних зі складом миючих засобів.

Екологічна свідомість ведення бізнесу стає важливою при виборі постачальника послуг та асортиментної політики. Торговий бізнес не може залишатися осторонь від загального напрямку руху світового ринку в бік екологізації, також важливо не допускати можливості використання грінвошінгу - псевдоекологічного поширення небезпечних i екологічно нестійких практик виробництва і споживання.

На сучасному етапі в торговельних мережах України поступово набувають популярності терміни «екологічний», «натуральний», «органічний», «безпечний», що вказує на екологічні переваги товару й зростання споживчого інтересу в цьому напрямі. На жаль, значна частина товарів ще не відповідають реальним вимогам екологічних критеріїв, проте стандартами України визначено чіткі вимоги до них.

\section{Література:}

1. Цибуляк А.Г. Екологізація економіки України в умовах розширення співпраці з ЄС. Науково-практичний журнал "Причорноморські економічні студіi”.' Одеса, 2016. Вип. 8. С. 31-35.

2. Декрет Кабінету Міністрів України «Про стандартизацію i сертифікацію». URL: http://zakon2.rada.gov.ua/laws/show/46-93.

3. Закон України № 1315-VII від 05.06.2014 «Про стандартизацію». URL: http://zakon2.rada.gov.ua/laws/show/1315-18.

4. Національний стандарт України ДСТУ ISO 9000:2015 (ISO 9000:2015, IDT). Системи управління якістю. Основні положення та словник термінів. Київ : ДП «УкрНДНЦ», 2016.

5. Держстат України, 2021

6. Андрєєва Н., Харічков С. Екологічно чисте виробництво: інституційні передумови, шляхи та механізми їх активізації в Україні. Економіст. 2015. № 10. C. $25-29$. 